\title{
Riding in Cars Between Men
}

\section{John M. Sloop}

Through an analysis of public discourse surrounding two different controversies featuring professional race car driver, Deborah Renshaw, this article foregrounds contemporary relationships between gender and (auto)mobility. It draws on both theories of gender performativity and media ecology to outline the ways in which the automobile as a technology influences gender performance and the ways in which the automobile is understood through cultural discourses that are already largely gendered. The essay uses the discourse surrounding the Renshaw case to problematize both contemporary gender norms and understandings of the relationship between prosthetic media and the body.

Keywords: Gender Performativity; Automobility; Deborah Renshaw; Homosociality; Prosthetic Media

The car has become an article of dress without which we feel uncertain, unclad, and incomplete in the urban compound... Cars have become the real population of our cities, with a resulting loss of human scale...--Marshall McLuhan ${ }^{1}$

What happens when women drive cars, instead of adorning men's cars, instead of sitting, fixed and still, draped across them? What happens when women wear cars instead of clothes? - Sharon Willis ${ }^{2}$

The highs and lows of NASCAR and ARCA driver Deborah Renshaw's 2002 racing season were extreme to say the least. ${ }^{3}$ During this one year, Renshaw first saw her star rise rapidly as the dual effect of her skill as a driver and of her role as a "victim" in a well-publicized "conspiracy" at the Nashville Speedway. By season's end, however, Renshaw's fortunes reversed as she was involved in a near career-ending disaster when the car she was driving during a practice session broadsided another car, instantly killing driver Eric Martin. While a number of lessons have been drawn from this case by race officials, it is also useful as one route by which cultural critics might draw

\footnotetext{
John M. Sloop is Professor of Communication Studies at Vanderbilt University. A version of this essay was presented at the 2003 convention of the National Communication Association in Miami, FL. The author would like to thank Robert Ivie, the very bright anonymous reviewers, Vanderbilt's "Working Papers in Gender and Sexuality Group," and Joan Faber McAlister. Correspondence to John M. Sloop, Department of Communication Studies, Vanderbilt University, Nashville, TN 37235, USA. E-mail: john.m. sloop@vanderbilt.edu
} 
lessons about the intersections of popular understandings of the proper performance of gender and the relationship between body media (i.e., prosthetics broadly defined) and the gendered body. As I will illustrate, first, the constraints of gender performativity - at least as described by Judith Butler ${ }^{4}$ - are thrown into relief not only in the reported actions and statements of those involved in this case but also in the discourse reporters use to describe those actions and statements. ${ }^{5}$ Second, while some contemporary discussions of the posthuman body (i.e., the changing meaning of the body as it merges with a wide variety of prosthetics and technologies) suggest possibilities for the blurring of gender norms, this case highlights the cultural constraints on such transitions.

The story, as conveyed primarily through print news reports, unfolds as follows. ${ }^{6}$ In early 2002, one who followed the lower divisions of NASCAR would likely have begun to notice the name "Deborah Renshaw" appearing repeatedly. Not only was Renshaw racing on a weekly basis, but she was also placing well in many of those races, for a short time leading the point standings for the weekly series at the Nashville Fairgrounds Speedway. Moreover, and perhaps more pointedly, Renshaw was being held forth as the "prototype" of female drivers by those in NASCAR circles who thought female drivers would be a way to expand the demographic of NASCAR's fan base. In short, she was positioned as a marketable female, combining driving skills with "ladylike" attractiveness.

In mid-July, however, events on the racing circuit moved Renshaw from the pages of local (regional and sport) press coverage to a broader realm of sports and news interest, garnering interview opportunities with Connie Chung, Bryant Gumble, and The Regis and Kelly Show, and news coverage in large market dailies as well as USA Today. ${ }^{7}$ Here is what is reported to have happened. On 14 July, competing driver Mark Day pooled money from almost all of the other (male) drivers racing that night, entered a car which pitted early in the race, and posted the $\$ 3,600$ fee required to have another driver's engine inspected. ${ }^{8}$ Understanding that the protest was a plot by most, if not all, of the male drivers, Nashville Fairgrounds Speedway President Dennis Grau received permission from NASCAR officials to void the protest. Renshaw's team, confident that the engine met regulations, insisted that Grau have it broken down and inspected. By the time the inspection was over, Renshaw had been disqualified. The inspectors found a cylinder hold less than one centimeter too large - a violation that Grau claimed would not by itself have given Renshaw's car any advantage. Nonetheless, rules dictated that Renshaw's sixth place finish, and the season points that would be accrued with that finish, be forfeited. In effect, the points she forfeited in this one race also ended her quest for the season title at the track.

The day following the protest and forfeiture, Renshaw declared publicly that she would never race in Nashville again, feeling humiliated and at risk because she was surrounded by male drivers who had chosen to gang up on her. However, public outcry against the group of male drivers - accompanied by dual assurances by highlevel NASCAR officials that Renshaw would not face such behavior again and that she (and her family) would be protected-encouraged her enough that she agreed to return to the track. When she did return, it was not only to the track but also to a 
media environment in which she was now in the role of the "star female driver" who had been ganged up on by a large number of boys-boys whose masculinity had been threatened by her driving skills. ${ }^{9}$ Moreover, precisely because of the attention that was given to the plot, NASCAR team owner Rick Goodwin also became aware of Renshaw. While acknowledging that he had never heard of Renshaw before the controversy, he hired her to be the driver of his Busch Series car for the 2003 season. ${ }^{10}$ Ultimately, the plot against Renshaw worked rhetorically in her favor, enabling her to garner a larger fan base, more sponsorship, a "promotion" for the 2003 season, and the opportunity to race faster cars on the ARCA circuit in 2002. ${ }^{11}$

With trouble seemingly behind her, Renshaw drove in a number of races at both small tracks and on the ARCA circuit with longer tracks and faster cars. In early October, while practicing at Lowe's Motor Speedway in Concorde, NC for the EasyCare 150, Renshaw's car broadsided the car driven by racer Eric Martin, who was killed instantly by the impact. While Renshaw underwent surgery for multiple fractures in her left foot and ankle, drivers and sports reporters began to question her skills, her level of responsibility for Martin's death, and, finally, ARCA safety regulations. As the year came to a close, not only did ARCA institute new policies as a result of this incident, but Renshaw lost her sponsorship deal with Goodwin and was implicitly and explicitly blamed for Martin's death.

When the discursive field that surrounded Renshaw during these events - a discourse that helped produce and resignify her "femininity" in this "masculine" domain - is understood as partially the product of the gendered history of the automobile, we have an interesting location from which to investigate the ways in which the "common sense" ideology of mass culture encourages the reiteration of particular gender norms. ${ }^{12}$ Thus, I focus specifically on the public discussion of Renshaw's story both as a way of bringing the sedimented discourses of gender's cultural "common sense" into relief and as a way of troubling those norms and expectations. ${ }^{13}$ I begin by outlining some of my assumptions about the automobile as a technology or (prosthetic) medium with implications for gender, gender's performative qualities, and, finally, the historical articulations made between and among gender, automobiles and stock car racing. Second, I provide a critical reading of the discourse concerning the plot against Renshaw early in the season and reporting about Renshaw after the death of driver Eric Martin. Ultimately, I see this case, like all cases of public controversy with gender as a primary focus, as a location or opportunity to problematize the particular configuration of gender performance and gender expectations loosely shared in contemporary US culture, as well as a route to further conversations about the body's relationship to technology. ${ }^{14}$

\section{The Automobile as Prosthetic and Cultural Object}

To begin to think about a relationship between cars and gender is to think of the automobile both as a medium or prosthetic for the body and as a discursive object that enters a culture with preexisting gender/sexual meanings. That is, we must think about the car both as an "extension of the self" and as an object of ideological 
meanings. Ultimately, there is a rhetorical tension between the ways in which the "automobile as medium/prosthetic" encourages an erasure of the importance of gender (via McLuhan's "loss of human scale") and sedimented cultural understandings of gender and of the automobile (Sharon Willis is concerned, after all, with women wearing cars rather than clothes).

In the first epigraph of this essay, Marshall McLuhan asks that the car-like all technologies - be understood as a prosthetic, yet another "extension of man" [ sic]. From this perspective, one interested in gender would ask, "Regardless of the cultural context in which the automobile emerged, what are its influences on cultural understandings of gender or sexuality?" That is, what are the ways in which the existence of the automobile as a dominant technology changed or transformed cultural understandings of gender because of the ways the car altered our relationship with geographic space and time? ${ }^{15}$ As cars become readily available, obviously enough, space and distance are changed; we can cover more ground and move more efficiently with the car than without, and this efficiency alters social relations and the meaning of particular locations. For example, as John Howard illustrates in his history of male homosexuality in the southern United States, as more and more people began to own cars, gay spaces - and a sense of a gay community - could develop more easily: "The automobile provided not only the means of transport, but also a place of intersection. The quasi-public space of the interior became the site for communication." 16 Transportation allowed the creation of a larger sense of communication and confirmation of marginal sexualities, and, as a result, it helped blur stable definitions and essential qualities. ${ }^{17}$ Further, Scharff suggests that the very existence of cars helped problematize gender because it began to blur public and "private" or domestic spaces, encouraging a slow devolution of the assignment of males to the public and females to the private. ${ }^{18}$

More directly, drawing upon the well-known work of Donna Haraway, Gilles Deleuze, Claudia Springer, and others, Rosi Braidotti has recently addressed the potential of contemporary "prosethetic"/cyborg technologies to aid a cultural rethinking of the meaning of the (post)-human body. ${ }^{19}$ Braidotti notes that one common characteristic of many early theories of the post-human body is a slightly utopian tendency to underscore the ways in which the human/technology merge aids a blurring or rethinking of gender subject positions. In such an equation, the automobile becomes one of many technological "prosthetics" which function as a supposedly gender-troubling/gender-blurring extension of the body. Hence, if we think of the car as body covering or as an extension of the body, it is a costume or prosthetic that is equally open to all drivers regardless of gender/sexuality and that functions "equally" for all, making each person equally fast, similarly shaped.

Only a moment's reflection, however, would tell us that the equation between technology and culture is not quite that smooth. Indeed, as John Jordan recently observed in drawing upon contemporary scholarship on the cyborg imaginary, notions of smooth cyberbodies are being challenged as undelivered and perhaps undeliverable. ${ }^{20}$ For example, in the case of automobiles, not only do most of us have some vague idea of what colloquially constitutes a "male" and a "female" car, but we 
know that cars, like all new technologies, enter a culture with gendered meanings that in turn shape its meaning. For example, as both Scharff and Sean O'Connell respectively discuss in their histories of gender and automobiles in the United States and in British society, the automobile was gendered since its inception, since marketing concerns drove our cultural understanding of the car almost as soon as it became a "product." As Scharff observes, the automobile was "born in a masculine manger and when women sought to claim its power, they invaded a male domain." ${ }^{21}$ Indeed, in underscoring this point, Scharff points out that when the car first appeared as a commodity, the word "traffic" was most commonly used as a disparaging word to refer to notions like "trafficking in drugs" or the ways in which women of low character were said to "traffic in charms." 22 A female driver was the cause of gender trouble, as no proper woman, a woman who fittingly "reiterated the expectations of gender behavior," could drive the car by definition. ${ }^{23}$ Moreover, Scharff argues that designers such as Henry Ford always tended to see the automobile - precisely because it was loud, dirty, and mechanical — as articulated strictly along gendered lines as a masculine machine. ${ }^{24}$

While the automobile's representation has certainly altered over time, Scharff's analysis illustrates that "while the auto transformed the particular places men and women went and the things they did, people remained, at the general level, embedded in their gendered identities, just as gender remained a critical category of American culture." ${ }^{25}$ Similarly, Judy Wajcman, acknowledging technology as a social construct and "femininity" and "masculinity" as malleable concepts, argues that technology in general is represented as "male" and, hence, to enter the world of the car, "to learn its language, women have first to forsake their femininity." ${ }^{26}$ Finally, while O'Connell, like Scharff, sees "women motorists" as "symbolic of shifting gender relations," his overall story is one in which the car is understood through the normative regulation of femininity and masculinity. ${ }^{27}$ Hence, for example, even when changes in the car were recommended and desired by both men and women (e.g., the ignition switch, the enclosed roof), such changes were represented as a feminization of the car in that they made the car less "manly." Even though women were driving and such changes became ubiquitous, these changes were also ones which reinforced, rearticulated, resignified cultural meanings of men and women. ${ }^{28}$ This "founding" ideology of the car haunts our present, continuing to factor into how we understand cars, how we market cars, and how we interact with other forms of transportation. ${ }^{29}$ In short, this ideological configuration writes gender onto the meaning of the prosthetics functions.

On the one hand, then, the automobile is a technology or medium that potentially encourages at least a situational erasure of gender - anyone can wear a car, and, because cars in some senses replace our bodies, they erase gender difference in particular ways. On the other, cultural historians have illustrated that the car was born within a culture of bi-gendered norms and has been consistently marketed and understood through the lens of those norms. As Braidotti notes of other media, the "alleged triumph of high-technologies is not matched by a leap of the human imagination to create new images and representations. Quite on the contrary, what I 
notice is the repetition of very old themes." ${ }^{30}$ While gender may indeed have been altered by the automobile, the circulation of common-sense ideology tends toward stability (i.e., people interpret events through the lens of their previous understandings of the world). The gendered body may move inside the structure of the automobile, but that body's gender still matters. Drawing on Fiske and Hartley, we might say that public arguments tend to "claw" meanings back to the familiar rather than to the new or transitional. ${ }^{31}$ Because of a desire for stable definitions, and because of a market system that rewards the popular or familiar over the strange and indeterminate, gender norms are difficult - although clearly not impossible - to displace.

Together, then, these two different impulses in the relationship of the automobile and the body emerge in the discourse surrounding the Renshaw case. On the one hand, because anybody can assumedly drive a car with equal skill regardless of gender, those involved in competitive racing must deny gender's significance in a way that is not true of most other sports. On the other hand, because automobiles and all body technologies have traditionally been articulated on hetero-normative, bi-gendered lines, it is never possible that just any-body is driving a car; rather, it is always a particular type of body - and the meanings articulated with that body - in the driver's seat. As a result, the Deborah Renshaw case, a case in which a woman finds herself in trouble (gender and otherwise) in a "male" sport, is perhaps the ideal location for understanding some of the contours of our shared gender ideology. Further, in laying bare the articulations that hold together cars and normative gender assumptions, such an analysis hopefully also helps dismantle such assumptions.

\section{The Trouble with Deborah Renshaw, a "First Woman" Racer}

\section{Homosocial Desire Between Cars}

In her classic analysis of homosocial desire, Between Men, Eve Sedgwick argues that homosocial (rather than homoerotic or homosexual) desire functions in part to mark the differences between men and women. More strongly, Sedgwick suggests that historically different shades of male and female homosociality may be taken as "articulations and mechanisms of the enduring inequality of power between women and men." 32 More often than not, Sedgwick observes, male homosocial relations exclude women from political formations generally held by men: "We can go even further ... to say that in any male-dominated society, there is a special relationship between male homosocial desire and the structures for maintaining and transmitting patriarchal power." 33 Sedgwick is not constructing a facile model that configures women as overtly disciplined and excluded by men in a heavy-handed manner. Rather, Sedgwick argues that men and women as a whole act in what could be considered a "common sense" fashion, assuming and naturalizing gender binarisms as the basis for much human behavior.

In the context of this case, when Renshaw began outperforming many of the men on the Nashville circuit, homosocial bonding can be seen as at work in the drivers' 
attempt to have Renshaw disqualified, excluding her from a traditionally masculine space. If we read Renshaw's success as a disruption of the male driver's "oval jerk," their conspiracy can be read as a protection of a homosocial space. ${ }^{34}$ Moreover, and perhaps more importantly, public denunciations of this "male" conspiracydenunciations which were seemingly meant to critique exclusion on the basis of gender-inadvertently reinforced the very gender binarisms the male drivers were protecting.

I wish to suggest that this hetero-normative assumption is rearticulated publicly in the following ways. First, despite repeated claims that gender is irrelevant in racing because the technology equalizes competition, Renshaw is repeatedly described in terms that emphasize her traditional female appearance and "highly cultured" feminine interests that are seemingly at odds with the aesthetic and cultural position of stock-car racing. Second, the male-female binarism is maintained through public discussions that describe the disqualification plot as a "soap opera" and as a "gang bang" and represent Renshaw as a traditional female victim. Third, Renshaw's driving ability is described through the cultural frame of the "bad female driver," with her success said to emerge solely as the result of public fascination with her gender.

The repeated claims made by Renshaw and others concerning the irrelevance of gender in racing emerges as the product of both the requirement that a competitive playing field be level for all and as a result of her featured role in what Ruth Rosen has called the "first woman" story - a mediated narrative of the "first" woman to enter any traditional male domains. ${ }^{35}$ Focusing on mass mediated stories that arose around "first women" in the 1960s and early 1970s, Rosen observes several common themes: the reports discuss the "first woman's" appearance and social status (i.e., married, children) and consistently deny gender's role in the lives of these women. More specifically, "first women" overtly claim that "being a woman had never harmed them, nor had it helped them," that men do not express hostility toward them, and that they feel just like "one of the guys." ${ }^{36}$ Finally, "first women" repeatedly stress that success comes from merit and from making the right choices. ${ }^{37}$ While Renshaw is clearly not the "first woman race car driver," such racers remain rare enough on any given circuit that much of the coverage of Renshaw puts her in a "sole woman" narrative that, despite its appearance 30 years after the stories Rosen reports, repeats much of their logic.

For example, in press coverage of Renshaw appearing before the "plot" at the Nashville Speedway, gender is repeatedly invoked in order to deny its significance. In an article in the Atlanta Journal-Constitution, Renshaw makes the following claim, inadvertently offering a summary of what Sarah Projansky refers to as "equality and choice postfeminism": ${ }^{38}$ "It's not gender that helps you win. It's the choices you make. .. . A woman is just as capable behind the wheel as any man." ${ }^{39}$ Moreover, an Associated Press story quotes competing driver David Binkley as observing of Renshaw: "When she puts that helmet on and climbs into her race car you can't tell if she's a man or a woman - she's just a race driver" (emphasis mine). ${ }^{40}$ In an almost identical statement made after he hired Renshaw, team owner Goodwin claims that "When you sit in that seat, you're not a man or a woman. You're a driver." ${ }^{41}$ What I 
want to emphasize is that such denials of gender relevance are always built with a caveat that is impossible to bring to fruition. The claim-overt or implied - is that one is neither male nor female "when you sit in that seat," but it is impossible to sit in that seat removed from cultural understandings when doing so. Bodies matter, Butler might remind us here, as they are interpreted through cultural meanings and discourses. Hence, one never sits in a driver's seat as an unmarked body; the body always signifies, always matters. In this case, Renshaw's body - a woman's body-is found in a place (not only a car but a race car) in which it does not "naturally" belong. Moreover, because Renshaw was so successful, because she was "passing" so convincingly, her gender became even more of an issue. The outcome of the races she participated in contradicted the cultural understandings of the meaning of that body in that seat. According to cultural gender logic, she was not supposed to win.

Renshaw, then, finds herself in a problematic situation. On the one hand, in order to fit fairly within the ideology of technology and "fair competition," she and others must continually emphasize that, in racing, gender is unmarked. On the other hand, cultural articulations of her body in a race car are ones that trouble gender expectations. As a result, as Butler notes, when gender expectations are troubled, the disciplinary constraints of culture (which work through representations, through public discussion, through the ways in which individuals discipline one another in everyday behavior) operate to encourage the gender-troubling parties to rearticulate their behavior to fit the expectations of proper gender behavior (or to explain how the improper behavior - here, racing - is only one aberration in an otherwise proper performance).

Day, the leader of the disqualification plot, may make the crassest male-female gender distinctions when he muses, "Maybe we're all a bunch of redneck racers. Maybe most drivers won't say it, but if they look at a woman, they'll think, 'What's she doing' here?' Hey, it's a man's sport. That's just the way it is," but he is certainly not alone in rearticulating those differences. ${ }^{42}$ For example, Renshaw's own reported voice and those of others describing her consistently work to emphasize her "feminine" and refined qualities. Renshaw's official website suggests that she "is not exactly the picture of your typical stock car driver. She is an educated, 26-year-old with a Bachelor's Degree." 43 Reporter Jack Wilkinson describes her in the Atlanta Journal-Constitution as different than male drivers, in effect, as feminine: "She is an attractive, pony tailed, personable, 25-year-old college graduate, the well-heeled daughter of a wealthy car dealer." ${ }^{44}$ Charleston's Post and Courier describes Renshaw as a "daddy's girl" with dark brown hair. ${ }^{45}$ Similarly, a Roanoke Times and World News reporter first observes Renshaw walking "into the Darlington Raceway media center wearing low-rider jeans with a wide black belt and a tight black knit shirt that exposed her midriff," then notes that "Renshaw has good looks, a college degree and acting school experience." 46 Finally, Renshaw's appearance on a local (Nashville) sports talk show also provides an example of her representation as a "proper" woman, different than we expect from women involved in racing. During a commercial break on the show, host Hope Hines informs Renshaw that the first three questions will be coming from women. He then pauses and adds that while the 
"first three callers are women, we don't know if they're ladies." Turning back and referring to Renshaw as "Ms. Deborah," he ultimately articulates Renshaw as a proper lady, as opposed to what we expect from women involved in racing. ${ }^{47}$ Indeed, Day might say, what is she doing here?

Reporting about the disqualification plot and Renshaw's behavior as a result of the plot also functions to stress Renshaw's proper performance of femininity (indeed, her difference from male drivers). The overall arch of the story as covered in multiple newspaper accounts would run something like this: Renshaw is the star of a soap opera in which a group of boys attempted to chase her away from their playground. While Renshaw at first tears up and runs away, she ultimately decides to stand up to the bullies. For example, an Atlanta Journal-Constitution article is headlined "A Stock Car Soap Opera." 48 The body of the article, after emphasizing Renshaw's good looks and personality, describes the events as "a juicy little stock car soap opera" in which the male racers ganged up on Renshaw in a fit of jealousy. In line with the representation of the event as soap opera, several reporters make note of Renshaw's emotional response to the disqualification, once again emphasizing and naturalizing gender difference despite the simultaneous attempts at gender erasure. For example, Teresa Walker of the Associated Press writes that while Renshaw was aware that some of the men at the track resented her, "their collusion to get her car disqualified got the best of her. ... Renshaw sat in the stands and cried. 'I'm a woman and women tend to have more emotions than men do, and they show it in different ways." 49

This narrative furthermore lends itself repeatedly to emphasizing that the "plot" pitted "boys" against "girls." Renshaw claims in the Commercial Appeal (Memphis), for example, that she had decided to return to racing because she "didn't want to leave the perception that the boys ran the girl off." ${ }^{50}$ Elsewhere, Renshaw is "some hot-shot girl," model." 53 In each case, we have a clear articulation that the differences between Renshaw and the male drivers is a vast one, marking Renshaw as different than her opponents and similar to other women.

Descriptions of the plot itself, and the ways the male drivers and Renshaw are configured in this plot, hauntingly recreate the dynamics of homosocial/homosexual triangulation and exclusion. Indeed, the single most common metaphor to describe the "conspiracy" is that it was a case of a group of boys "ganging up on a girl." This is a metaphor that invokes violent exclusion through physical and sexual (i.e., gang bang) terror. The language of such stories creates a scenario in which men gather together as one to attempt to eliminate or exclude Renshaw; that is, they create bonds between men in order to exclude the "so-called feminine in men" and the masculine in women. ${ }^{54}$

Throughout the coverage of the disqualification plot, one finds persistent references to a gang of men who pick on an innocent "girl." On several occasions when interviewed about her initial decision to quit racing in Nashville, Renshaw herself employs the metaphor: "When 12 or 13 men gang up ... [t]he good ol' boys can have their track back." ${ }^{5}$ Reporter John Romano of the St. Petersburg Times more bluntly observes, "If you have not heard the story, a bunch of male drivers ganged up 
on the track's only female competitor in a shameful display of piston envy." Similarly, reporter Jack Wilkinson summarizes the story as one of "A bunch of good ol' boy drivers ganging up on ... this poor innocent little girl" (emphasis mine). ${ }^{57}$

As Sedgwick points out, the discourse of the "gang bang" always implies a strong homosocial (sometimes homosexual) desire between the male aggressors. Hence, the understanding of the "plot" as a group of men attempting to exclude Renshaw also works to reconfigure the "proper performance" of masculinity of the men involved in the plot, especially the leaders. For example, the crowds at the Nashville race track the following weeks reportedly not only began to openly support Renshaw more enthusiastically than they had before, but also began to openly question the masculinity of the male drivers. Reporter Jack Wilkinson provides the following illustration of one fan's reaction at seeing Day the week following the disqualification: “'Crybaby!' cried [racing fan] Joe Ryman ... over a cascading chorus of boos. 'You've always been a little sissy crybaby!"” (emphasis mine) ${ }^{58}$ Moreover, racing fan Harold Bryan reportedly began to shout that all of the conspirators were a "bunch of wimp rednecks." 59 Such terms - "wimp," "sissy" and "crybaby" - coupled with the narrative in which the men ganged up on an innocent girl works in a cultural logic which questions the men's ability to properly perform as men.

The male-female binary is similarly upheld by the employment of the historically grounded representation of women as unskilled drivers. In Taking the Wheel, Scharff observes that although cars as a technology were represented early in their history as dangerous machines, when they became seemingly essential or necessary for culture, the blame for deaths by automobiles had to shift from the technology itself to particular users of the technology. (If the technology itself was at fault, the solution is to get rid of the technology. If, however, particular users are at fault, the solution is to keep them from using the technology.) While blame was initially placed on pedestrians for accidents, blame slowly moved to female drivers. Scharff observes, "Early critics of women drivers, much like their contemporaries who opposed women's entry into higher education and woman suffrage, cited three presumed sources of women's inferiority at the wheel: emotional instability, physical weakness, and intellectual deficiencies." 60 Such charges are clearly linked to almost all transportation technology. As Constance Penley and Projansky have illustrated, "lack of skill" charges were made against both Christa McAuliffe and child airplane pilot Jessica Dubroff in narratives and news reports published after the Challenger disaster and the Dubroff tragedy, respectively. ${ }^{61}$

Given the historical roots of this trope and our awareness of its functioning in contemporary culture, when one claims that Renshaw is a "bad driver," one is once again illustrating that Renshaw can never be "just" a driver. Rather, claims about her relative lack of skills once again discipline her back into the proper iteration of cultural understandings of "femininity" and therefore once again reiterate the gender norms themselves. Hence, when Day tells an Associated Press reporter that he questions "the ability of women to compete," finding most of them to be bad drivers, he reiterates this norm. ${ }^{62}$ More directly, when Day tells reporter Teresa Walker, "I'm not upset at Deborah because she's a woman. I'm upset at her because she's a bad 
driver," ${ }^{33}$ he simultaneously denies the importance of gender and reinvokes its proper performative iteration.

In sum, in the discourse surrounding the disqualification plot, we see the ways in which - again, despite the insistence that gender is invisible in the racing arenagender consistently raises its head to generally reinforce traditional and "proper" cultural understandings of gender and sexuality. Combining our cultural understandings of "male" and "female" behaviors with the articulations of gender/sexuality which have historically emerged around cars, we find a discursive field that is fraught with a tendency toward stability. That is, while meanings change, and while the "proper iterations" of gender/sexuality are indeed historical, the intersections of gender, occupation, and automobiles create a discourse that partially re-stabilizes when faced with transgression (although never completely). Moreover, given the economic costs of racing, which require that drivers be both skilled and attractive in order to gain sponsorship, Renshaw finds both ideological and economic incentives for proper gender behavior. Renshaw, like all "first women," is represented as highly cultured and educated, hard working, and able to conclude that gender is irrelevant, while she simultaneously is faced with a culture that not only consistently tests her proper femininity but also provides her with economic incentives for proper performance. In the end, despite the discourse of gender blindness articulated with prosthetic technologies, gender largely overdetermines, rearticulating and re-signifying the gender of the body in that car.

\section{Judging and Regulating Renshaw}

O'Connell observes that by 1993, over half a million deaths had occurred on British highways alone as a result of automobile accidents. ${ }^{64}$ As I noted above, in public arguments, this high number of deaths must be balanced against the benefits the technology brings to a society. Again, rather than place the blame on the technology itself, public discourse could justify the use of the car more effectively if the blame were put on individual types of drivers, or other factors external to the technology itself (e.g., poorly designed roads, insufficient laws). Early on, and despite "factual evidence" to the contrary, female drivers became an effective and convincing scapegoat in the public imaginary. ${ }^{65}$ One of the implications of this configuration of women as dangerous drivers is that new laws and regulations concerning "automotive safety" often were created and/or enforced only after highly publicized accidents involving women. ${ }^{66}$ As I will argue below, in the death of driver Eric Martin, this familiar pattern emerges, one clearly articulated along the lines of gender. Not only are Renshaw's general driving skills called into question as a result of the accident, but new track rules and regulations that would have been useful previous to the accident are only called for and enacted afterwards.

To recall, in early October 2002, while Renshaw was practicing at Lowe's Motor Speedway in Concord, NC for the Easy Care 150 ARCA RE/MAX race, peer driver Eric Martin lost control of his car in the fourth turn of the 1.5 mile track, evidently as the result of a blown tire. Renshaw, a half track behind Martin, came around turn 
four - reportedly 15 seconds after his blow out - at $160 \mathrm{mph}$, broadsiding Martin's car and killing him instantly. ${ }^{67}$ The press coverage that followed the accident, in addition to persistently retelling the story of the "plot" against Renshaw in Nashville, implicates Renshaw as the cause. ${ }^{6}$

For instance, on the day following the accident, reporter Lindsey Young helps us wonder: "At question is why Renshaw, who according to eye witnesses hit Martin several seconds ... after three other cars had avoided Martin's car, was not informed of Martin's spin or did not see the car." ${ }^{\prime 9}$ Given a narrative setting in which we are reminded repeatedly that female drivers are very rare, we are invited to presume that the three cars which avoided the accident were all driven by men. Further, Tony Fabrizio of the Tampa Tribune observes that "something terrible had to go wrong for her to have hit Martin at nearly full speed. Witnesses estimate that the collision took place as much as 15 seconds after Martin's initial wreck." ${ }^{70}$ If others had avoided Martin's car, we are asked to wonder, why did Renshaw, with 15 seconds' warning, have the accident?

In the days that followed, two arguments crystallized. First, Renshaw was unprepared as a driver to race in this league. Second, new regulations were needed to force racing teams to be more careful in the future. An example of the first argument appears in the Chattanooga Times when Track President H.A. "Humpy" Wheeler and driver Bobby Labonte are said to have "expressed surprise that Renshaw didn't know what was ahead of her," and both wondered "if she was qualified to be racing on Lowe's 1.5 mile oval."71 Chris Jenkins of USA Today investigates on-line discussion sites and notes that Renshaw's lack of skill became the primary focus almost immediately: "Big-Time drivers were questioning her right to race such powerful cars. ... The implication: She was in over her head and now somebody was dead." 72 Further, after reporting that Winston Cup drivers had declared Renshaw "guilty" in kangaroo courts up and down the garage area the day after the accident, Jenkins quotes Wayne Hixon, the owner of Martin's car, as saying that he did not "think Renshaw belonged on the track. 'It is racing, some of it is,' he says, 'but some of it is stupidity."'73

In a second line of argument, calls for new regulations meant to protect drivers against incompetence are raised as a result of the accident. Although Lowe's speedway had witnessed eight driver's deaths since opening, many presumably from a similar "cause" (i.e., the fact that the driver's spotters - those who warn drivers about accidents on the track - were not required to sit in the grandstand during practice sessions), ${ }^{74}$ calls for new regulations did not emerge or were not effective until after (and seemingly as a result of) the Renshaw-Martin accident.

Paralleling the ways in which Renshaw is blamed for the accident, calls for regulation emerge almost immediately in news reports. For example, Jerry Gappens, the spokesman for the Speedway, noted the day after the accident that "this is something ARCA officials need to look at."75 Similarly, the New York Times reported that ARCA series president Ron Drager wanted to see a change in rules as a result of the accident. ${ }^{76}$ Tying the two lines of argument together, Tony Fabrizio of the Tampa Tribune argues that the accident should not only force ARCA to change rules about 
spotters, but also investigate rule changes that might keep inexperienced drivers like Renshaw off the track. ${ }^{77}$ A mere three days after the accident, ARCA indeed did pass new regulations that required spotters to be in the grandstand whenever team drivers were on the track. ${ }^{78}$ Hopefully, it is obvious that I am not suggesting that these new regulations were a "bad idea" - clearly, this is an easily implemented precaution. Rather, what I want to point out is the fact that the regulation became an exigency only after this particular accident.

A comparison of the Renshaw case to discourse and actions following the death of Dale Earnhardt at NASCAR's Daytona 500 indicates some gendered differences. In February 2001, USA Today's Jenkins notes that “Three drivers died of similar severe head injuries last year. Justifiably, the cry goes out: What can be done to make racing safer?"79 In this case, however, reports make it clear that any pressures for change in safety regulations are emerging from outside the sport rather than inside and that the accident was inherent to racing itself rather than the fault of any individual, including driver Sterlin Marlin, who was involved in the accident. For example, Gwen Knapp of the San Francisco Chronicle observes that while safety changes will probably be implemented, it will be at the insistence of fans rather than as the desire of NASCAR itself: "The changes will come now. The outsiders will insist." ${ }^{80}$ While changes did come, most notably in the use of head and neck restraint systems by NASCAR drivers, these changes took a full year compared to the immediate reaction in the Renshaw case. At several points during public discussion of the accident, NASCAR President Mike Helton noted, "We're simply not going to react for the sake of reacting," ${ }^{\prime 1}$ and CART medical advisor Steve Olvey noted that "The key thing at a time like this is to make sure we don't get a knee-jerk reaction." 82

In addition, while Renshaw was posited as at fault in her accident, the Earnhardt accident ultimately gets positioned as inherent to the sport, after initial attempts were made to place the blame on individuals. For example, immediately after the accident, Nick Harvey, team manager of the PPI Motorsports Winston Cup Team says of racing: "It's kind of like boxing. You can try to make it as safe as you want, but a guy still has to hit another guy." 83 More pointedly and directly, Dale Earnhardt Jr., son of the Winston Cup champion, openly rebuked those attempting to place blame on individuals for the accident: "Any notion or any idea of placing blame on anyonewhether it be Sterlin Marlin or anybody else, for that matter - is ridiculous and will not be tolerated." ${ }^{84}$ Hence, compared to the Renshaw accident, Earnhardt's death is posed as inherent to racing and the fault of equipment rather than individuals. Rather than attempt to rush to provide regulations, "studies" are conducted to make sure that there were no "knee-jerk" reactions to the accident.

If common-sense ideology still largely operates with a configuration in which male drivers are largely evaluated as individuals while female performance is more closely tied to the "natural compulsions of sex," it should be no surprise that the exigency is to create a regulation that protects individual men from all female drivers. ${ }^{85}$ Again, while Renshaw and others may consistently repeat that racing is not about gender, that it is about the "choices" one makes, gender concerns largely overdetermine the understanding of Renshaw's skills, of the "cause" of an accident, and of the need for 
regulations. The cultural logic again pulls in many different directions. While Renshaw as "first woman" must make it clear that she will work hard to achieve success on her own and that others have mostly given her a "fair shake," she is simultaneously configured as part of "women" as a whole and carries their inefficiencies onto the track.

\section{Renshaw as "Media Hoax"}

As noted above, despite the fact that other women have raced in both local and national circuits before Renshaw, her story was treated in news media very clearly along the patterns of the "first women" stories outlined by Ruth Rosen. Again, one of the patterns Rosen observed is that the "first woman" story provides great attention to the "woman" while telling a story in which her skills and efforts, rather than her gender, led to her success or failure. While the Renshaw case clearly follows this pattern early in the year, one of the more interesting aspects of the case later in the year, after the death of Eric Martin, is the way in which media coverage of the "first woman" story itself becomes an area of blame in Martin's death. That is, while the "first woman" story itself works to erase gender, when tragedy arises, "the media" is blamed - and blames itself - for paying too much attention to a woman and thereby placing her in a position to cause damage to herself and/or to others.

While not using the language of "first women" stories, Projansky argues that in the case of "first women pilots" of any sort (i.e., first balloonist, first female in space, etc.), news reporters and media representatives have had similar responses when these "firsts" have resulted in tragedy. For example, Projansky notes, in the cases of balloonist Pearl White, pilot Amelia Earhart, and "child pilot" Jessica Dubroff, media coverage ultimately "admonished 'the media' itself for paying attention to a 'media hoax,' a story about a woman who was 'not really a pilot' or who was 'not really a good pilot." 86 That is, media outlets, through editorials or through publishing the views of those close to the tragedy, ultimately chastised "the media" itself for providing so much attention to a "first woman" that the woman oversteps her abilities, resulting in injury and death of the pilot and others. ${ }^{87}$ In effect, such reports offer an apologia for the fact that their own spectacle encouraged a poorly qualified woman, even though that early coverage attempted to erase gender from the equation. Ultimately, the news coverage acts as an admission that gender matters after all.

In Renshaw's case, the critique of her popularity as unearned and as potentially dangerous is made early on by some of her competitors (especially those involved in the disqualification plot), even though it is initially discounted by reporters who are aligned with the "first woman" erasure of gender. For example, Day suggested that Renshaw is a dangerous driver because she is "so star-struck that she can't focus on racing." ${ }^{\text {M }}$ Moreover, when Goodwin hired Renshaw to be his Busch Series driver, the Tampa Tribune notes as an aside that while Goodwin knew little about Renshaw's "driving ability, he thought she could be a marketing gem - a 'female' Jeff Gordon." ${ }^{9}$ More recently, a letter to the Tennessean makes the following argument after 
suggesting that Renshaw was getting opportunities above her skill level: "I'm not a sexist, but I am for fairness. In racing, you have to earn your right to be there. How many men racers who are more qualified don't get opportunities because they are not women? A lot. I'm sure." 90 In each case, news outlets report that others think Renshaw is receiving too much attention based on gender rather than skill, even though the news reports themselves highlight Renshaw's skills as a driver rather than as a woman.

Paralleling Projansky's claims about coverage of women in flight, media reports later self-reflexively concede that perhaps their coverage was in fact part of the problem. For instance, John Romano of the St. Petersburg Times offers the following concession to Renshaw's competition: "In a small way, their complaints had merit. Renshaw's growing popularity owed more to her gender than her skills." 91 After the Martin accident, reporter Jenna Fryer suggests that "Renshaw's racing career was on a fast track" due to the media attention she was receiving, and that this perhaps encouraged Renshaw to enter upper-division racing circuits before she was prepared. $^{92}$ Similarly, the Tampa Tribune observes after the accident that while Renshaw was "unknown outside Tennessee until this year, she gained attention in July when fellow drivers at Nashville's Fairgrounds Speedway pooled their money to file a protest.... [T] he resulting news coverage caught the eye of Busch Series team owner Goodwin" and hence moved Renshaw quickly up the racing ladder. ${ }^{93}$ Again, I am not suggesting that self-reflection by individual reporters and/or media outlets is a bad idea; rather, I would like to suggest that such arguments ultimately work within a logic that implies that Renshaw was unqualified precisely because she is a woman. Moreover, given this configuration and the fact that it is a theme oft-repeated in narrative accounts of female firsts, the cultural logic becomes one which must muse, if Renshaw is in "over her head" because of gendered publicity, that perhaps this is true of all female drivers.

\section{Conclusion}

As cultural histories of the automobile have illustrated, the entry of automobiles into mass culture as a technology - as a prosthetic or "extension of man" — functioned to trouble a number of different existing cultural logics (e.g., demarcations of public and private, the boundaries of geographic space) and opened up new social possibilities (e.g., improved zones for homosexual encounters, altered notions of gender, changing patterns of dating). That is, the automobile as a technology (i.e., as a medium) altered relationships among people - the automobile as medium carried its own message. ${ }^{94}$ However, and as the oft-repeated critique of media determinism would have it, this is not the entirety of the story. While cars may have become the "real population of our cities," already contained distinctions of class, race, gender, sexuality, and occupation - a culture with a performative language that encouraged its own reiteration, that encourages its own resignification even when, for instance, "women drive cars, instead of adorning men's cars." ${ }^{96}$ With Braidotti, we see here that the technological 
imaginary cannot wipe out gender (or class) distinctions as they are ultimately protected by other means. $^{97}$

While I am not denying that ongoing changes have occurred in the logics of gender and sexuality and am not denying that there are ways in which consumers can actively rethink cultural logics, I am using this case to note ways in which contemporary ideological "common sense" remains powerful, reiterating and resignifying. The case of Deborah Renshaw provides a "first woman" narrative that ends in tragedy, a first woman narrative that simultaneously denies the importance of gender while ultimately reemphasizing it in its own logic. It is a story in which "choice" and "skill" are at first highlighted over gender, ultimately only to be found subsumed once again under gender expectations.

In short, the Renshaw case reminds us that gender is never, and perhaps can never be, invisible. Moreover, when one intersects the logic of gender with its articulation around automobiles generally and racing specifically, one finds the expectations of gender more rigidly binding, more difficult to ignore. As I have illustrated, in the discourse surrounding both of the stories about Renshaw's 2002 season, gender is resignified in multiple ways - in Renshaw's own reported words, in other people's discussion about Renshaw and in the logic of the news reports themselves. For example, Renshaw is reported as suggesting that women naturally react emotionally in ways different than men; Renshaw's appearance and clothing are emphasized in particularly gendered ways and in ways absent from descriptions of most male drivers; her male peer group "gangs up" to discipline her for, in effect, receiving too much of the attention that they deserve. Moreover, after the death of fellow racer Eric Martin, Renshaw receives blame in a context that questions her abilities as a driver, and-given Renshaw's connection to future female drivers via the "first woman" narrative and male-female differences that are reiterated in reports about her-in a context that questions the ability of all female drivers and all potential female racers.

In The Car in British Society, O'Connell goes to some pains on several occasions to make his reader aware that the "ideological" intersections of gender and automobiles generally operate "automatically," as common sense, that bi-gendered logic was assumed historically by most men and women in their relationships with automobiles. ${ }^{98}$ As O'Connell puts it, the history of the automobile is "not a story of brutish men denying women their freedom. ... What has been explained is the role played by gender ideology in the normative regulation of femininity and masculinity within the context of motoring." 99 Whether behaving to gender expectations automatically or thinking about the consequences of not doing so, we largely reinforce the logic of those expectations, perhaps especially so when those expectations are troubled.

Hence, when Renshaw finds herself riding in cars "between men," men who bond socially and professionally through her exclusion and the preservation of male space, Renshaw initially decides to "let the old boys" have their game back. On those grounds, gender performative expectations are protected. However, those expectations are perhaps more importantly - or rather, more insidiously — protected by the common sense with which people operate when Renshaw decides to continue racing. 
When NASCAR's “diversity council," for example, posits Renshaw as the prototype of women drivers who could attract a larger female audience (she is attractive and well spoken), they are implicitly acknowledging that she is the "proper" type of female driver. ${ }^{100}$ Or, when a reporter notes, after Renshaw was hired by Goodwin, that “[r]acing insiders don't know much about her driving ability, but they say she could be a marketing gem" because she has "good looks, a college degree and acting school experience," that reporter is acknowledging - and simultaneously reiterating - the power of capital on proper gender performance. ${ }^{101}$ Or, when Goodwin is quoted in the same news report as saying that " $[\mathrm{w}]$ hen you sit in that seat, you're not a man or a woman" and observes that he was interested in hiring Renshaw because "as an attractive woman, she's attractive to sponsors," we understand that one is never just a driver, never just sitting in that seat. ${ }^{102}$ When a television host consistently refers to Renshaw as "the lovely Deborah Renshaw" and contrasts "the lovely Deborah Renshaw" with "unladylike" callers, we know that he understands the proper performance of gender and assumes that his audience shares that understanding. ${ }^{103}$

Ultimately, then, this essay should be read as an attempt to underline the discursive weight of gender ideology and its intersection with the cultural logic of automobiles and of automobile racing. Moreover, this is an attempt not only to trace out some contemporary links between gender and the automobile, between gender and a particular occupation, but to make an argument about those links that will help us all remember to problematize them. Revolutions are slow, as Raymond Williams continues to whisper, because meanings often change at a snail's pace. In bringing "common sense" into relief, I mean to encourage each of us to trouble this case in particular and to continue to remain vigilant in problematizing the constraints of gender ideology in all other domains. ${ }^{104}$

\section{Notes}

[1] Marshall McLuhan, Understanding Media: The Extensions of Man (New York: McGraw-Hill, 1965), 217-18.

[2] Sharon Willis, High Contrast: Race and Gender in Contemporary Hollywood Film (Durham, NC: Duke University Press, 1997), 108.

[3] I will try to clarify the different racing circuits in which Renshaw competed. To parallel loosely with professional baseball, Renshaw raced in what could be seen as unaffiliated minor leagues (local small tracks, ARCA series) as well as NASCAR minor leagues, and was headed for NASCAR's Busch series. In short, she competed during that year in the equivalent of Single and Double A baseball and was preparing through Rick Goodwin to move to Triple A.

[4] I am assuming that Butler's theses have become widespread enough that I do not need to rehearse her arguments thoroughly in the body of the essay. For Butler, to say that gender is 'performative' is to suggest that regardless of the physicality of gender, it is something that is understood, or has meaning, through discourse or culturally accepted practices, including appearance, manners of speaking, occupational roles, choices of sexual partners, and so forth. See Judith Butler, GenderTrouble: Feminism and the Subersion of Identity (New York: Routledge, 1990), 139. Moreover, given how heavily policed gender norms are in popular culture, Butler observed, bi-gendered heterosexual norms become materialized, naturalized as if they were essential rather than contingent. As a result, individuals "perform" gender to a 
great deal without reflection, simply behaving in ways that "make sense" given their own gender identification. Further, they inspect other people's gender performances without a great deal of regard or thought given to the way in which we "police" one another's gender behaviors. Performativity, then, "cannot be understood outside of a process of iterability, a regularized and constrained repetition of norms.... This repetition is what enables a subject and constitutes the temporal condition for the subject. This iterability implies that 'performance' is not a singular 'act' or event, but a ritualized production, a ritual reiterated under and through constraint, under and through the force of prohibition and taboo, with the threat of ostracism and even death controlling and compelling the shape of production, but not, I will insist, determining it fully in advance," Judith Butler, Bodies that Matter: On the Discursive Limits of "Sex" (New York: Routledge, 1993), 95.

[5] I, of course, assume that the discourse is far more complex than I posit it in these opening sentences, and I trace out the subtleties of the discourse later in the essay. Indeed, this "gender discipline" occurs precisely because the events described in this paper were ones that at first opened up possibilities for stretching public understandings of proper gender performance. It might be more correct to note that the discourse analyzed here only partially reiterates traditional bi-gendered heteronormativity.

[6] To clarify, I am not claiming that this telling of the story is "authentic" or true. Rather, the story I tell here is one I have drawn together out of over 50 different newspaper articles gathered through Lexis-Nexis searches. While I will be referring to individual articles in detail later in my analysis, this version is more simply my general "reading" or "gathering of fragments" of those newspaper articles. For a discussion of this methodology, see Raymie E. McKerrow, "Critical Rhetoric: Theory and Praxis," Communication Monographs 56 (1989): 91-111 or, more recently, Kent A. Ono and John M. Sloop, Shifting Borders: Rhetoric, Immigration, and California's Proposition 187 (Philadelphia, PA: Temple University Press, 2002), 1-25. I take mine to be a reading that would be familiar and fair to most other people who read these reports. In addition, I also refer to a small number of radio broadcasts as well as Renshaw's appearance in late 2002 on a local talk show.

[7] Renshaw consistently makes the point that she turned down most of these interviews as she thought it would be bad for NASCAR as a whole to have a "gender fight" and would have worked against her career as the news would focus on her gender. See, for example, John Romano, "Chauvinism Rears Its Ugly Gearhead," St. Petersburg Times, 26 July 2002, 1C, and Tony Fabrizio, "Controversy Opens Way for Renshaw," Tampa Tribune, 31 August 2002, Sports 12.

[8] NASCAR rules for this series require that a driver can only protest the cars that finish ahead of them. The driver of the pitted car, Scottie Smothers, was making his first race at the track for the sole purpose of quitting early so that he would be able to protest Renshaw's engine.

[9] Again, I am not making "truth" statements here; rather, I am reiterating press claims about these events. Claims about threats to the other driver's masculinity are both implicit and explicit in a variety of reports.

[10] Busch Series is one step below Winston, NASCAR's "major league." Goodwin had recently moved his 2002 Busch Series drivers into his Winston (now Nextel) Cup car.

[11] ARCA (the Automobile Racing Club of America), not affiliated with NASCAR, uses Winston (Nextel) Cup style stock cars, which travel 60-80 mph faster than Renshaw drove in the late Model Series at Nashville. See Jenna Fryer "Renshaw's Career Now in Question," Chattanooga Times/Free Press, 11 October 2002, D1. ARCA is generally a step taken by drivers who want to move from small tracks to Busch and Winston (Nextel) series racing.

[12] I was tempted to discuss both gender and sexuality throughout the paper as the two are certainly tied together culturally; however, because the case most overtly discusses gender and most often only alludes to sexuality, I will generally frame the paper in terms of gender. As I will illustrate (but not highlight), the case also relies on class and racial norms in the resignification of what it means to be a "proper" NASCAR driver. 
[13] That is, my goal is to help trouble gender norms and expectations precisely by illustrating how efficiently and powerfully "dominant mass mediated" discussions of gender work toward closing down gender trouble. Such closure and reiterations of gender norms are never complete, however, and it is my hope that my illustration of disciplinary discourses will work to help individual readers loosen their own gender expectations.

[14] I realize, of course, that "U.S. culture" is not a particularly meaningful term given the wide variety of audiences, media outlets, and cultural groups that exist. What I mean to signify is: (a) I am not making claims for a world wide configuration of gender expectations; (b) I understand the gender expectations are historical, although history does have material influence on the present; and (c) "dominant" media outlets provide, and work with, loosely shared understandings of gender expectations. My assumption is that these expectations are also shared by audiences because, in order to gain and maintain an audience to sell to advertisers, mass media outlets must be loosely within the parameters of their audience's expectations.

[15] When one employs or encounters McLuhan, one must always be aware of the always available (always necessary) critique of McLuhan as a "media determinist." Regardless of whether or not McLuhan's writings warrant the criticism that has cohered around his thesis, it is certainly true that his emphasis on media as "extension of the self" emphasized technological changes over cultural changes rather than allowing insights from both technological and cultural criticism. For a good summary of McLuhan, criticisms of McLuhan and reworkings of McLuhan's theses, see Ronald J. Deibert, Parchment, Printing, and Hypermedia: Communication in World Order Transformation (New York: Columbia University Press, 1997).

[16] John Howard, Men Like That: A Southern Queer History (Chicago: University of Chicago Press, 1999), 4.

[17] I should point out that Howard's book also discusses issues of class and "gender" in minor ways.

[18] Virginia Scharff, Taking the Wheel: Women and the Coming of the Motor Age (Albuquerque: University of New Mexico Press, 1991), 1-50.

[19] Rosi Braidotti, Metamorpheses: Towards a Materialist Theory of Becoming (Cambridge, UK: Polity Press, 2002), 244-63. Obviously, I am over-generalizing Braidotti's claims in summarizing an entire chapter. Nonetheless, what I hope to point to here are the ways in which contemporary cultural discourses problematize alterations in our common understandings of gender.

[20] John W. Jordan, "(Ad)Dressing the Body in Online Shopping Sites," Critical Studies in Media Communication 20 (2003): 253. Indeed, almost all recent scholarship in this area would make this claim. The last decade has witnessed article after article which draws back on the earlier utopian visions of technology.

[21] Scharff, 13. Similarly, Sean O'Connell, The Car and British Society: Class, Gender, and Motoring, 1896-1939 (New York: Manchester University Press, 1998) begins his chapter on gender and the car by observing that "the agency that gender came to have in shaping ideas about car use has ultimately prevented millions of women from taking to the driving seat" (43).

[22] Scharff, 3-4.

[23] Moreover, both Scharff and O'Connell argue that women who raced cars were seen as being especially "gender troubling" because their behavior worked as a double contradiction against the "rules of gender performativity" (i.e., they were not only enthusiastic about driving cars but also competitive) (Scharff, 68-79; O'Connell, 96). In addition to marketing plans, this understanding of the female racer as "unfeminine" woman was rearticulated and reemphasized in news reports as women like Catherine McClulloch of the Illinois Equal Suffrage Association sponsored women-only automobile trips to publicize suffrage but also in literature as multiple links were produced between female drivers and lesbianism. See 
Scharff, 79 and O'Donnell, 211. O'Donnell makes this link through a reading of Radclyffe Hall's The Well of Loneliness and other novels. However, both Scharff, 107 and O'Connell, 49-50 also suggest that representations of woman drivers' corps members during World War II - women such as Gertrude Stein and Alice Toklas - also carried the underlying suggestion of lesbianism.

[24] Scharff, 15-16, 54-55.

[25] Scharff, 166.

[26] Judy Wajcman, Feminism Confronts Technology (Cambridge, UK: Polity Press, 1991), 45

[27] O'Connell, 220.

[28] Scharff, 57-58, 222; O'Connell, 64-69. The electric starter and a variety of colors are two other innovations that all people seemed to want but were attributed to "feminizing" the car, making it less brutal. Scharff, 132, reports that the "color and paint" division at General Motors in the 1920s was referred to derisively as "the beauty parlor" and was one of the few divisions that employed a large number of women.

[29] While I do not mean to belabor the point, I want to stress the ways in which gender differences - bi-gendered normativity - remain an underlying assumption (no longer as overt as it was in O'Connell and Scharff's analyses) in all "public discussions" of transportation technologies. For example, in her analysis of female car sales staff, Helene M. Lawson, Ladies on the Lot: Women, Car Sales, and the Pursuit of the American Dream (Lanham, MD: Rowman \& Littlefield, 2000) argues that the gendered behavior expectations of men and women on sales lots are strongly bi-gendered and heteronormative, and hence, many of the characteristics associated with normal male behavior are also those aspects of personality said to create successful car sales staff (e.g., the push for the hard sale, ability to work rather than raise children, and ability to take full credit for sales that are not their own (Lawson, 34, 43, 64, 75, 90). Or, to turn to discourse concerning space shuttle technology, Constance Penley, "Spaced Out: Remembering Christa McAuliffe," Camera Obscura 29 (1992): 179-213, has argued that the public discourse concerning Christa McAuliffe illustrates the ways in which gendered discourse and gender expectations continue to function and continue to work against the success of women in NASA programs. Similarly, Sarah Projansky, "Girls Who Act like Women Who Fly: Jessica Dubroff as Cultural Troublemaker," Signs 23 (1998): 771-807, in an analysis of the Jessica Dubroff flight, suggests that similar gendered discourses operate in the ways in which we, as a public culture, configure air transport.

[30] Braidotti, 250.

[31] John Fiske and John Hartley, Reading Television (New York: Methuen, 1978), 85-91.

[32] Eve Sedgwick, Between Men: English Literature and Male Homosocial Desire (New York: Columbia University Press, 1985), 5.

[33] Sedgwick, 25.

[34] I am indebted to Charles Morris for suggesting this phrase.

[35] Ruth Rosen, The World Split Open: How the Modern Women's Movement Changed America (New York: Penguin, 2000), 302-8.

[36] Rosen, 303.

[37] Rosen, 306.

[38] Sarah Projansky, Watching Rape: Film and Television in Postfeminist Culture (New York: New York University Press, 2001), 72-79.

[39] Stephania H. Davis, "Auto-Racing Group is Crossing Barriers," Atlanta Journal and Constitution, 7 March 2002, 1JD, emphasis mine.

[40] "Renshaw Returns to Track Where Plot Got Her Disqualified," Associated Press State and Local Wire, 4 August 2002.

[41] Gene Sapakoff, "Busch Series' Renshaw Just the Driver NASCAR Needs," Post and Courier, 31 August 2002, 7C. 
[42] Jack Wilkinson, “A Stock Car Soap Opera," Atlanta Journal-Constitution, 3 August 2002, 1E. When coupled with comments about Renshaw's "sophistication" and education, Day's reference to "redneck racers" clearly illustrates that issues of class are at work here as well. While I do not want to deny that there are articulations that connect gender and class, for the purposes of this essay, I remain focused on gender. Clearly, other analyses of this case could draw the distinctions somewhat differently.

[43] http://www.deborahrenshaw.com/about.cfm (accessed 11 March 2003).

[44] Wilkinson, 1E.

[45] Sapakoff, 7C.

[46] Tony Fabrizio, "Controversy Opens Way for Renshaw," Tampa Tribune, 31 August 2002, Sports 12. See also Dustin Long, "NASCAR Rolling in Right Direction," Roanoke Times and World News, 31 August 2002, C5 and Sapakoff 7C.

[47] "Sportsline with Hope Hines."

[48] Wilkinson, 1E.

[49] Teresa M. Walker, "Renshaw: Plot by Fellow Drivers Devastating, but Won't Stop Her," Associated Press, 19 July 2002, Sports News.

[50] Steve Smith, "Female Driver Vows to Race Despite Plot," Commercial Appeal, 24 July 2002, D2.

[51] Romano, 1C.

[52] Wilkinson, 1E.

[53] "Sportsline."

[54] Sedgwick, 25.

[55] Walker, "Renshaw." See also Walker, "Kentucky," C11, "Male Drivers Plot to Get Woman Disqualified, Drive Her from Track," Associated Press, 15 July 2002, Sports News, and "Some Unsporting Behavior," Commercial Appeal 16 July 2002, D1.

[56] Romano, 1C.

[57] Wilkinson, 1E.

[58] Wilkinson, 1E.

[59] Wilkinson, 1E.

[60] Scharff, 26. Similarly, in line with Scharff's observations, Sean O'Connell argues that traditional arguments against female drivers in England were based in genetics, evolution, and, surprisingly, women's lack of sexual satisfaction (leading some publications to recommend that men satisfy their wives' sexual needs in order to help them be safer drivers). While any observer of popular culture could vouch for the continuation of this articulation in a variety of forms today, Helene Lawson's ethnography of women who work at car dealerships (and their employers) illustrates that many dealers overtly refuse to hire women because they perceive them to know so little about driving or about the technology of automobiles (34).

[61] Projansky, 790; Penley, 179-80.

[62] "Male Drivers," Sports News.

[63] Walker, "Renshaw," Sports News.

[64] O’Connell, 114.

[65] O'Connell, 120. It would be easy to suggest that "the elderly" have become another scapegoat to deaths caused by automobiles.

[66] O'Connell, 120-23.

[67] See "ARCA Driver Martin Killed When Disabled Car is Struck," Newsday, 10 October 2002, A84 and Lindsey Young, "Hixson's Martin Killed in Crash," Chattanooga Times, 10 October 2002, D1 for detailed reports about the accident.

[68] I want to make clear at the outset of this analysis that I am not making an argument about "blame." That is, I am neither defending nor criticizing Renshaw. I am more interested in the ways that - given the multiple narratives that could have been created - one particular narrative about the accident becomes dominant. 


\section{J. M. Sloop}

[69] Young, D1.

[70] Tomy Fabrizio, "ARCA Oversight Can Be Corrected," Tampa Tribune, 12 October 2002, Sports 12. For other examples of this same logic, see "Crash Kills ARCA Rookie," Atlanta Journal-Constitution, 10 October 2002, 3D; Viv Bernstein, "Stock-Car Series Mulls Rule Change," New York Times, 11 October 2002, D7; Fryer, D1; "Drivers Work Hard to Forget Tragedy," News \& Record, 12 October 2002, C1.

[71] Fryer, D1.

[72] Chris Jenkins, "Haunted-But Undaunted," USA Today, 6 February 2003, 1C.

[73] Jenkins, 1C. See also Fryer, D1.

[74] Technically, the spotters only had to stand on the team's trailer during practice sessions, which made it difficult for the spotter to see the full track. See "Crash Kills" for a discussion of this difficulty. While the regulation would ultimately affect everyone, the discourse makes it clear that it is an attempt to protect drivers from incompetent peer drivers and teams.

[75] Young, D1.

[76] Bernstein, D7. See also Fryer, D1.

[77] Fabrizio, "ARCA," Sports 12. See also "NASCAR Considers Changes After Crash," New York Times, 12 October 2002, D7.

[78] Reports of this change are widespread. See Rick Minter, "Fatality Brings Spotter Requirement," Atlanta Journal-Constitution, 13 October 2002, 6E; David Caraviello, "All Too Often, Racing Learns Its Lesson Too Late," Post and Courier, 13 October 2002, 7C; Dustin Long, "Rule Change Sets Spotter Placement," News \& Record, 13 October 2002, C13; Dave Kallman, "Something Stinks at Road America," Milwaukee Journal Sentinel, 18 October 2002, 8C; "No Blame Assigned in Fatal ARCA Crash," St. Petersburg Times, 20 October 2002, 5C; Tony Fabrizio, "In Memory," Tampa Tribune, 20 November 2002, Sports 5.

[79] Chris Jenkins, "Curbing the Risks," USA TODAY, 20 February 2001, 1C. I analyzed 50 articles following the Earnhardt case for this example.

[80] Gewn Knapp, "Another Call for Reason," San Francisco Chronicle, 20 February 2001, E1.

[81] H.A. Branham, "Death Reopens Car Racing Questions," Tampa Tribune, 20 February 2001, 1.

[82] "He Said It," The Gazette, 20 February 2001, E1. For a reiteration of this claim a full six months later, see Joanne Korth, "How Earnhardt Died," St. Petersburgh Times, 1A.

[83] H.A. Branham, "Death Reopens Car Racing Questions," Tampa Tribune, 20 February 2001, 1.

[84] Liz Clarke, Washington Post, "Probe: Seat Beat Failed," 24 February 2001, D1.

[85] Scharff, 28.

[86] Projansky, 790.

[87] Projansky, 790.

[88] Walker, "Renshaw," Sports News.

[89] Fabrizio, "Controversy," Sports 12; see also Long, "NASCAR," C5.

[90] Tim Oliphant, "Driver Renshaw Hasn’t Paid Racing Dues Yet," Tennessean, 8 July 2003, 7A.

[91] Romano, 1C.

[92] Fryer, D1.

[93] Fabrizio, “ARCA," Sports 12.

[94] As a rhetorician, I am not suggesting that we can discuss technologies outside the realm of discourse. I am simply suggesting that different technologies do have different influences on meaning, given the particular culture in which they emerge.

[95] McLuhan, 217-18.

[96] Willis, 108.

[97] Braidotti, 245.

[98] Again, this is not to say that people do not actively resist such articulations. It is, rather, to suggest that this cultural logic-like all ideology_-works because most people assume its logic most of the time. 
[99] O’Connell, 220.

[100] Walker, "Kentucky," C11.

[101] Fabrizio, "Controversy," Sports 12.

[102] Sapakoff, 7C.

[103] "Sports Line."

[104] As a critic influenced heavily by both Foucault and Butler, I am not assuming that we can be "free" of ideology or that there is a space for the "pure expression" of gender. Rather, I hope that in "shaking up common sense," we are simultaneously encouraged to think of multiple possibilities. 